\title{
HOLOCENE ENVIRONMENTAL CHANGES IN WESTERN HUNGARY
}

\author{
Zsuzsanna Szántó \\ Institute of Nuclear Research of the Hungarian Academy of Sciences, Laboratory of Environmental Studies, 4026 Debrecen, \\ Bem tér 18/c, Hungary. Corresponding author. Email: aszanto@atomki.hu. \\ Zsófia Medzihradszky \\ Hungarian Natural History Museum, Department of Botany, 1087 Budapest, Könyves Kálmán krt. 40, Hungary. \\ Email: medzi@bot.nhmus.hu.
}

\begin{abstract}
We review the reasons for change in paleoecological conditions and their effects on different cultures at the beginning and during the Holocene period in western Hungary using radiocarbon data combined with paleoecological and paleolimnological results. Two sites were investigated in the southern and northern part of the ancient bay of Balaton Lake: Keszthely-Úsztatómajor and Főnyed I. ${ }^{14} \mathrm{C}$ dating of 2 core samples represented a chronology from $11,000 \mathrm{cal} \mathrm{BC}$ to $2000 \mathrm{cal}$ $\mathrm{BC}(10,700 \mathrm{BP}$ to $3700 \mathrm{BP})$ and from $6200 \mathrm{cal} \mathrm{BC}$ to $1200 \mathrm{cal} \mathrm{BC}$ (7300 BP to $3000 \mathrm{BP})$, respectively. A relatively constant inverse sediment accumulation rate was observed in both cases $(23 \mathrm{yr} / \mathrm{cm}$ and $33 \mathrm{yr} / \mathrm{cm}$, respectively). In the case of Fönyed I, a sharp break was observed in the sedimentation curve around 6000-4800 cal BC (6000 BP). Changes in the vegetation due to human activity were observed in a larger extent only at the end of Late Neolithic, with the most significant changes detected in the landscape coinciding with the presence of Lengyel III culture in the region. The appearance of higher amounts of pollen of cereals at the sites proved the presence of crop cultivation. However, the role of plant cultivation may have been limited for the ancient inhabitants of the Kis-Balaton region due to a limited amount of soil suitable for agriculture and due to the extensive water table. Further changes in vegetation were observed during the Late Copper Age (Baden culture) and the period of Early and Middle Bronze Age, respectively. Signs of forest clearing during the period have not been detected and the increased peak of Fagus indicates climatic change. The low intensity of anthropogenic activity should not be attributed to geographic isolation.
\end{abstract}

\section{INTRODUCTION}

Paleoecology, geology, geoarchaeology, and archaeology contribute to various aspects of the spatial and temporal dimension of the human condition (Bradley 1985). Paleoecological techniques and records can be used for reconstructing human communities' environments and human impacts in the ancient ecosystem. Pollen analysis is the primary technique to reconstruct past environmental conditions (Birks and Birks 1980). Pollen grains and spores can be used to reconstruct the vegetation of a region and changes in vegetation composition are used as an indication of variation in environmental conditions (i.e. climate, natural disturbance, or human interference). Combining pollen analysis with radiocarbon dating provides an important tool used for the precise delineation of vegetation shifts and climatic episodes in the region (Pilcher 1993). The development and refinement of ${ }^{14} \mathrm{C}$ dating techniques have allowed palynologists to construct influx pollen diagrams (Maher 1972), and if a reasonably accurate sedimentation rate is available, pollen concentrations may be converted to pollen influx rates. Thus, it is critical for pollen studies to have adequate chronological control such as ${ }^{14} \mathrm{C}$ age determinations.

To determine to what extent human activities in the region have induced changes in the vegetation and to what extent regional vegetation changes are climate-induced, we investigated and attempted to reconstruct the history of vegetation change using analysis of pollen from sediment cores recovered from 2 sites situated in the northern and southern part of the studied region.

\section{STUDY AREA}

Two sites of interest in western Hungary are parts of a large mire complex at the ancient bay of Balaton Lake: Keszthely-Úsztatómajor on the northern portion and Fónyed I on the southern portion.

(C) 2004 by the Arizona Board of Regents on behalf of the University of Arizona Proceedings of the 18th International Radiocarbon Conference, edited by N Beavan Athfield and R J Sparks RADIOCARBON, Vol 46, Nr 2, 2004, p 691-699 
(Figure 1). Several archeological studies have been done in the area (Sági 1966; Költő and Vándor 1996) and 7 settlements of Middle Neolithic culture were excavated and dated.

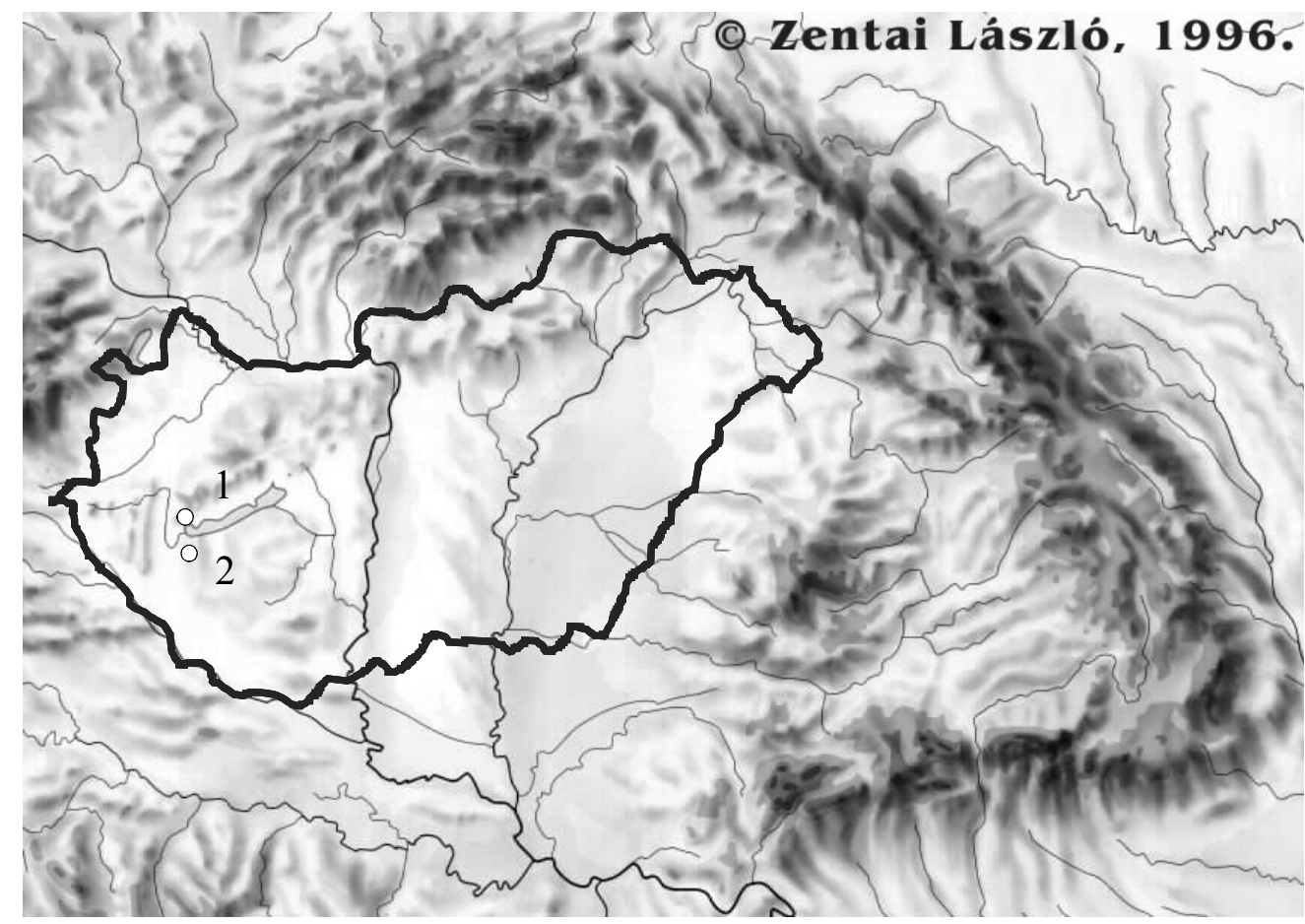

Figure 1 Map showing the location of (1) Keszthely-Úsztatómajor and (2) Fónyed I ( $\bigcirc$ = core location).

Keszthely-Úsztatómajor is situated south from Hévíz Lake between the Hévíz and the Úsztatómajor channel. Today, most of the area is uncultivated with a high level of groundwater. Modern vegetation in the area is tall sedge vegetation which is influenced by the thermal water outflow of Hévíz Lake (Medzihradszky 2001a).

Fônyed I is situated west of the village of Fônyed. Today, the site area is covered by $20-50 \mathrm{~cm}$ of water. Vegetation is mostly sedge with a small territory areas of planted forest (Medzihradszky 2001b).

\section{MATERIALS AND METHODS}

\section{Sample Preparation}

The 2 sedimentary sequences were obtained from boreholes $5.8 \mathrm{~m}$ and $4.8 \mathrm{~m}$ deep, respectively, using a Russian type 5-cm-diameter peat corer. Cores were wrapped in plastic film, aluminum foil, and plastic bags and stored at $4{ }^{\circ} \mathrm{C}$ before analysis.

The cores were divided into sections of 10-15 $\mathrm{cm}$. After physical pretreatment and removal of any rootlets or visible contamination, the peat samples were pretreated with the acid/alkali/acid (AAA) method. Samples were leached in $2 \% \mathrm{HCl}$ at $80{ }^{\circ} \mathrm{C}$ for $24 \mathrm{hr}$, rinsed with distilled water, then heated in $2 \% \mathrm{NaOH}$ for $24 \mathrm{hr}$, rinsed again with distilled water, and finally washed with $2 \% \mathrm{HCl}$ (until $\mathrm{pH}$ 3 is reached), filtered, rinsed, and dried. The chemically pretreated sample was combusted to $\mathrm{CO}_{2}$ 
in a controlled oxygen stream. Gaseous impurities (like traces of $\mathrm{NO}_{\mathrm{x}}$ ) and the excess of $\mathrm{O}_{2}$ unused during combustion were removed by passing the produced $\mathrm{CO}_{2}$ through a hot copper furnace. The purified $\mathrm{CO}_{2}$ was trapped into a stainless steel vessel using liquid nitrogen and measured by gas proportional counting (Hertelendi 1979). The multicounter ${ }^{14} \mathrm{C}$ dating system consists of 9 electrolytic copper proportional counters filled with $\mathrm{CO}_{2}$. The overall precision of the system for modern carbon samples was better than $4 \%$ after a counting period of 7 days (not including random errors in the process of chemical pretreatment and preparation). The $\delta^{13} \mathrm{C}_{\mathrm{PDB}}$ value was used to correct ${ }^{14} \mathrm{C}$ activity. Calibration of ${ }^{14} \mathrm{C}$ dates to calendar yr was performed using the Calib 4.0 program (Stuiver and Reimer 1993).

\section{Pollen Analysis}

The cores were subsampled at $5-\mathrm{cm}$ intervals and the samples were processed for pollen analysis using standard techniques (Berglund and Ralska-Jasiewiczowa 1986; Erdtman 1943; Stockmarr 1971). Pollen identifications were based on the descriptions and identification keys in Faegri and Iversen (1989), Moore et al. (1991), the pollen atlases of Reille (1992, 1995), and on the reference pollen collection of the W Szafer Botanical Institute of the Polish Academy of Sciences. To reduce statistical error, a minimum of 1000 pollen grains were counted at each stratigraphic level. Pollen abundance was expressed as a percentage of the sum of all pollen grains originating from terrestrial vegetation, namely, the sum of arbor pollen (AP) and the non-arbor pollen (NAP).

\section{RESULTS AND DISCUSSION}

Three forms of data were extracted from the sediment cores collected from the 2 sites:

1. Stratigraphic (sediment),

2. Chronostratigraphic (age),

3. Biostratigraphic (pollen).

Stratigraphic results were based on the description of the mineralogical properties of sediments related to their conditions of deposition.

Chronostratigraphic results were based on ${ }^{14} \mathrm{C}$ dates obtained from peat samples separated from sediment cores. Peat is representative of an environment characterized by high biological productivity, low mineral input, and shallow water.

Biostratigraphic results were presented on either relative (percentage) and or absolute (influx) pollen diagrams. In percentage diagrams, the number of grains of each pollen taxon was expressed as a percentage of the total pollen sum for a given sediment sample. A change in the percentage of one of the taxa was assumed to represent a change in vegetation composition.

\section{Lithostratigraphy}

The stratigraphy of the sediments within the sites was established analyzing 2 cores of $5.8 \mathrm{~m}$ and $4.8 \mathrm{~m}$ length, respectively, and described in Table 1.

\section{Chronology}

${ }^{14} \mathrm{C}$ dating was made on the 2 core samples of $310 \mathrm{~cm}$ and $225 \mathrm{~cm}$ length, and represented a chronology from $11,000 \mathrm{cal} \mathrm{BC}$ to $2000 \mathrm{cal} \mathrm{BC}(10,700 \mathrm{BP}$ to $3700 \mathrm{BP})$ and from $6200 \mathrm{cal} \mathrm{BC}$ to $1200 \mathrm{cal} \mathrm{BC}$ ( $7300 \mathrm{BP}$ to $3000 \mathrm{BP}$ ), respectively. The data presented here represent the first attempt to provide a ${ }^{14} \mathrm{C}$-dated record for the Kis-Balaton region. The ${ }^{14} \mathrm{C}$ dating was essential, but as yet only provides the initial measure of sediment ages. ${ }^{14} \mathrm{C}$ dates are presented in Table 2 and Table 3 and were used to derive the age-depth curves (Figure 2). 
Table 1 Lithology of the cores from Keszthely-Úsztatómajor and Főnyed I.

\begin{tabular}{|c|c|c|}
\hline Depth $(\mathrm{cm})$ & Keszthely-Úsztatómajor & Fônyed I \\
\hline $0-20$ & \multirow[t]{2}{*}{ Organic mud } & $\begin{array}{l}\text { Blackish organic mud, plant fibers and roots, } \\
\text { shell debris }\end{array}$ \\
\hline $\begin{array}{l}30-50 \\
50-60\end{array}$ & & \multirow[t]{2}{*}{$\begin{array}{l}\text { Thin layer of fine sand mixed with shell } \\
\text { debris }\end{array}$} \\
\hline $60-70$ & $\begin{array}{l}\text { Mineralized layer, intermixed } \\
\text { with sand grains and mud }\end{array}$ & \\
\hline $\begin{array}{l}70-80 \\
80-100\end{array}$ & \multirow{5}{*}{ Midbrown fibrous peat } & Mixed peat with shell debris \\
\hline $\begin{array}{l}100-110 \\
135-150\end{array}$ & & $\begin{array}{l}\text { Bright limestone, mixed with mud and } \\
\text { visible pieces of plant fibers; peat is missing }\end{array}$ \\
\hline $155-165$ & & Blackish, organic mud \\
\hline $180-190$ & & Fibrous peat \\
\hline $\begin{array}{l}190-200 \\
205-210\end{array}$ & & \multirow[t]{2}{*}{ Black-brown mature peat } \\
\hline $220-230$ & \multirow{2}{*}{$\begin{array}{l}\text { Mixed peat with visible plant } \\
\text { debris }\end{array}$} & \\
\hline $240-250$ & & \multirow[t]{2}{*}{ Sandy silt, intermixed with a gravel layer } \\
\hline $270-290$ & Plant debris, loose peat & \\
\hline $\begin{array}{l}290-300 \\
340-350\end{array}$ & $\begin{array}{l}\text { Dark brown fibrous peat, trace } \\
\text { of mineralization }\end{array}$ & \multirow{3}{*}{ Coarse sand with little organic mud } \\
\hline $360-400$ & $\begin{array}{l}\text { Fine gray sand with carbonate } \\
\text { deposition and charcoal pieces }\end{array}$ & \\
\hline $\begin{array}{l}400-480 \\
480-580\end{array}$ & $\begin{array}{l}\text { Coarse sand with little organic } \\
\text { mud }\end{array}$ & \\
\hline
\end{tabular}
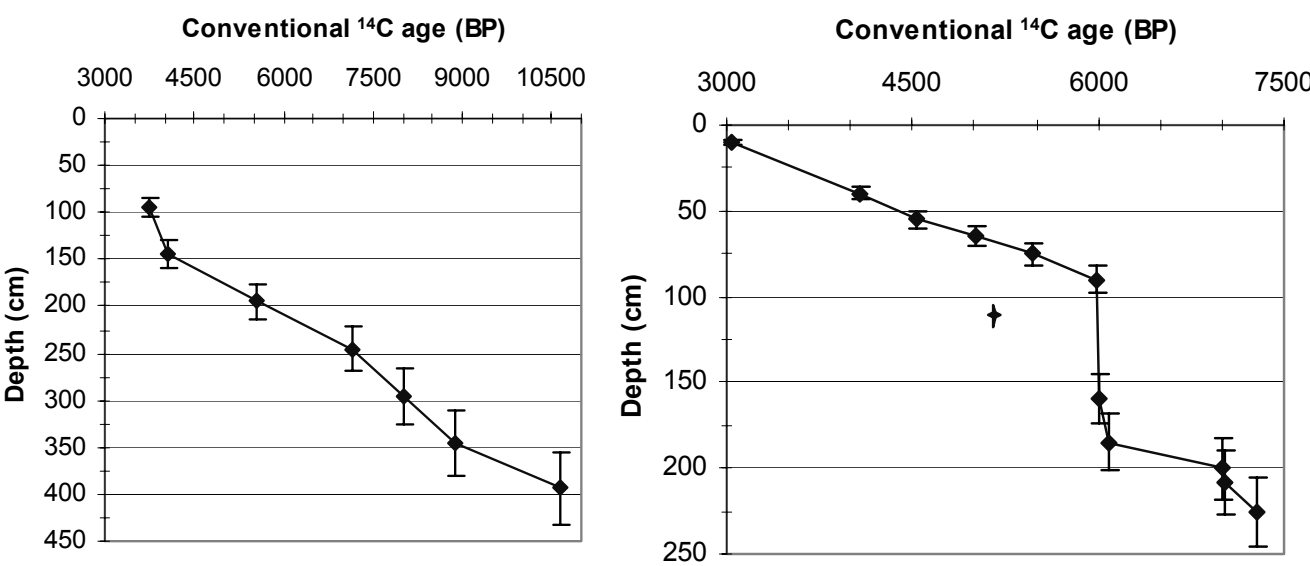

Figure 2 Sediment depth to ${ }^{14} \mathrm{C}$ age relationship for Keszthely-Úsztatómajor (left) and Fónyed I (right). Lines connecting each plotted point are interpolated sediment accumulation rates.

We noted an apparently anomalous date in the Fônyed I site core. The date at 100-110 $\mathrm{cm}$ depth was younger than expected and may be due to either humic infiltrates of younger age or the admixture of younger material. The age-depth curve (derived by linear interpolation with the Tilia 2.0 program) also illustrates that the date at $110 \mathrm{~cm}$ falls outside the expected range. For the purpose of site chronology, this date has been excluded. 
Table $2{ }^{14} \mathrm{C}$ and calibrated ages of peat samples from Keszthely-Úsztatómajor.

\begin{tabular}{cccc}
\hline $\begin{array}{l}\text { Depth } \\
(\mathrm{cm})\end{array}$ & $\begin{array}{l}\text { Conventional } \\
{ }^{14} \text { C ages (BP) }\end{array}$ & $\begin{array}{l}\text { Calibrated age (BC) } \\
1 \sigma(68.3 \%)\end{array}$ & Lab code \\
\hline $90-100$ & $3730 \pm 58$ & $2199-2033$ & deb-5036 \\
$135-150$ & $4073 \pm 67$ & $2710-2492$ & deb-5038 \\
$190-200$ & $5559 \pm 74$ & $4456-4336$ & deb-5083 \\
$240-250$ & $7154 \pm 70$ & $6078-5958$ & deb-5082 \\
$290-300$ & $8021 \pm 107$ & $7091-6775$ & deb-5061 \\
$340-350$ & $8864 \pm 161$ & $8218-7793$ & deb-5044 \\
$390-400$ & $10,657 \pm 128$ & $10,948-10,700$ & deb-5085 \\
& & $10,495-10,458$ & \\
\hline
\end{tabular}

Table $3{ }^{14} \mathrm{C}$ and calibrated ages of peat samples from Keszthely-Úsztatómajor.

\begin{tabular}{clll}
\hline $\begin{array}{l}\text { Depth } \\
(\mathrm{cm})\end{array}$ & $\begin{array}{l}\text { Conventional } \\
{ }^{14} \text { C ages }(\mathrm{BP})\end{array}$ & $\begin{array}{l}\text { Calibrated age }(\mathrm{BC}) \\
1 \sigma(68.3 \%)\end{array}$ & Lab code \\
\hline $0-20$ & $3030 \pm 55$ & $1376-1218$ & deb-7711 \\
$30-50$ & $4085 \pm 60$ & $2850-2810$ & deb-7909 \\
& & $2700-2523$ & \\
$50-60$ & $4530 \pm 55$ & $3352-3299$ & deb-7717 \\
& & $3244-3117$ & \\
$60-70$ & $5010 \pm 60$ & $3924-3865$ & deb-7925 \\
& & $3819-3718$ & \\
$70-80$ & $5475 \pm 70$ & $4371-4249$ & deb-7718 \\
$80-100$ & $5980 \pm 65$ & $4928-4783$ & deb-7833 \\
$100-110$ & $4890 \pm 55$ & $3718-3639$ & deb-7720 \\
$155-165$ & $6000 \pm 75$ & $4970-4817$ & deb-7928 \\
$180-190$ & $6080 \pm 55$ & $5048-4896$ & deb-7725 \\
$195-205$ & $7010 \pm 160$ & $6007-5736$ & deb-7929 \\
$205-210$ & $7030 \pm 95$ & $5991-5818$ & deb-7937 \\
$220-230$ & $7275 \pm 70$ & $6203-6073$ & deb-7727 \\
\hline
\end{tabular}

Based on the analysis of ${ }^{14} \mathrm{C}$ dates, the deposition time (inverse sediment accumulation rate) for the 2 cores was determined as $23 \mathrm{yr} / \mathrm{cm}$ for Keszthely-Úsztatómajor and $33 \mathrm{yr} / \mathrm{cm}$ for Főnyed I. According to the ${ }^{14} \mathrm{C}$ data for Fónyed I, there appeared to be a rapid peat accumulation around $4800 \mathrm{cal} \mathrm{BC}$ (6000 BP) with a deposition of approximately $70-75 \mathrm{~cm}$ of a sandy layer. This acceleration of sediment accumulation might be associated with some environmental change, possibly flooding. The deposition time for the Fônyed I site was calculated for the upper part of the sedimentation curve before the rapid sedimentation event occurred.

\section{Landscape History}

The pollen data covers the time period from $11,000 \mathrm{cal} \mathrm{BC}$ to $2000 \mathrm{cal} \mathrm{BC}(10,700 \mathrm{BP}$ to $3700 \mathrm{BP})$ for Keszthely-Úsztatómajor and the period from $6200 \mathrm{cal} \mathrm{BC}$ to $1200 \mathrm{cal}$ BC (7300 BP to $3000 \mathrm{BP}$ ) for Fônyed I. In archaeological terms, this spans the Early Neolithic to Middle Bronze Age. The results from the ${ }^{14} \mathrm{C}$ dating and pollen analysis were plotted versus depth (Figure 3).

Statistical procedures were used to zone the data. In both cases, the pollen diagrams were divided in 4 local pollen assemblage zones (LPAZ) based on the changes in the representation of major arboreals and non-arboreals. The local vegetation changes have been determined during the Holocene as follows: 


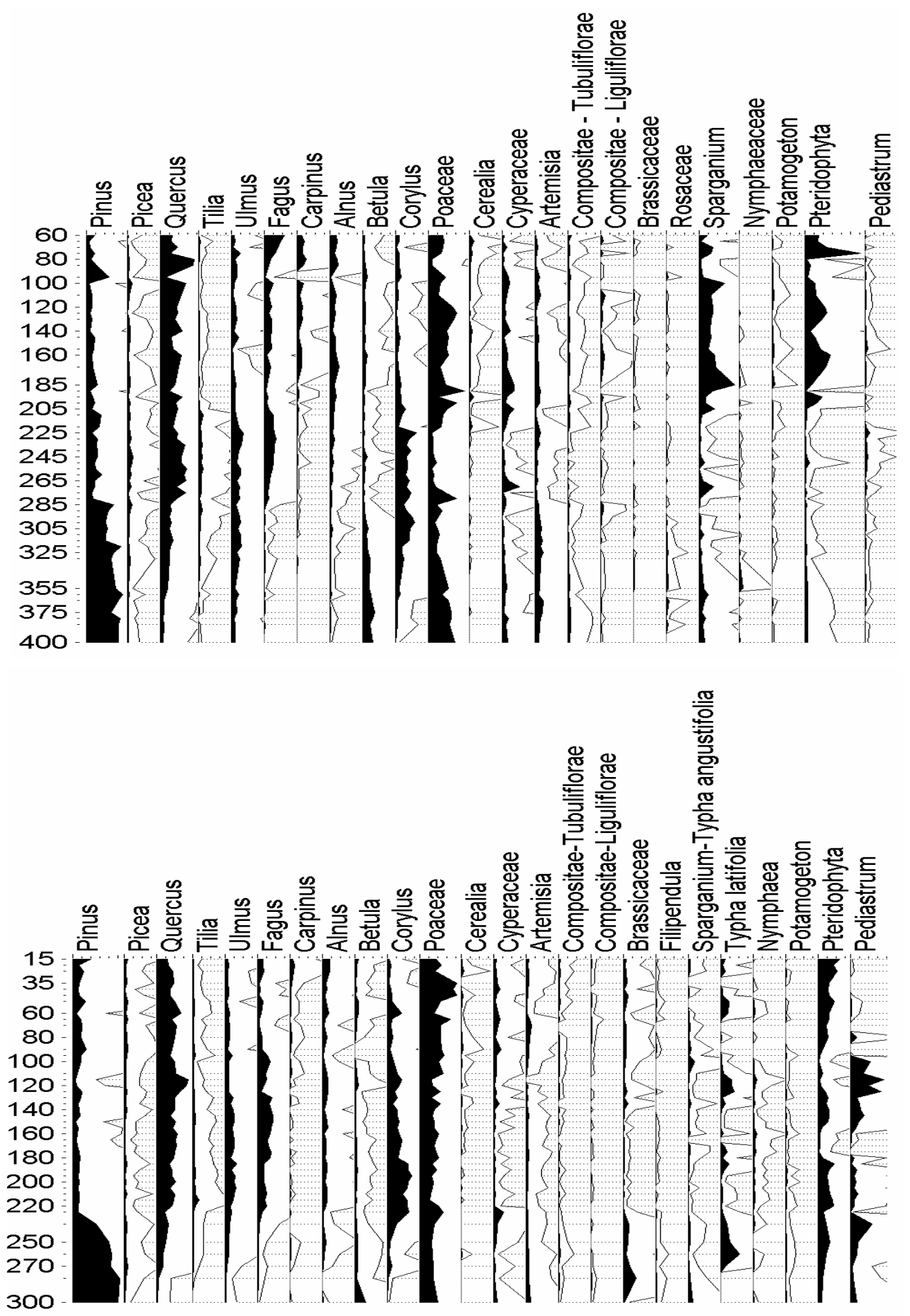

Figure 3 Pollen diagrams for Keszthely-Úsztatómajor (above) and Fônyed I (below) 


\section{LPAZ I-10,500-6500 cal BC (10,700-8000 BP)}

In this zone, the arbor and non-arbor pollen ratio of the spectra - apart from small variations - was equal, $80-20 \%$. Among the tree taxa, the Pinus had a high value, about 30-50\%, and Betula reached $15 \%$. From the very beginning of the zone, the continuous presence of Picea was observed, and the presence of other deciduous trees such as Quercus, Ulmus, Tilia, and a few pollen grains of Fagus were detected as well. Poaceae is approximately $30 \%$ with about $10 \%$ Artemisia. There were low numbers of the aquatic pollen (e.g. rushes), but some grains of the Nymphaeaceae refer to open surface water and higher water level. The presence of hazel was also recorded (25\%), a sign of a warm and dry climate.

\section{LPAZ II-6500-4400 cal BC (8000-5500 BP)}

The vegetation remained stable until about $8000 \mathrm{BP}$, when the tree arboreal peak increased and the herbaceous pollen percentages decreased. This zone represented a forestation stage, where the Quercus, Ulmus, and Fagus dominated the forest vegetation, but Tilia was also a characteristic element. Pinus decreased from $40 \%$ to $10 \%$, while Quercus reached 30\%, Tilia about 4-5\%, and Fagus had an average of $10 \%$. For Fônyed I, an extremely high peak in Pediastrum is observed. The forests closed and the first Cerealia pollen grains appeared.

\section{LPAZ III-4400-3300 cal BC (5500-4500 BP)}

The decreasing AP and increasing NAP pollen peaks were characteristic in this zone. Significant decreases of Tilia and Ulmus were observable. Quercus showed a more or less stable curve at $20 \%$. The percentage of Carpinus increased, while the presence of Fagus persisted. The Corylus pollen curve had a gradual and permanent decrease. The expansion of a wide diversity of herbaceous taxa was observed: an increased percentage of Sparganium-Typha angustifolia and ferns was detected. At this time, opening of the forests was observable. In the vegetational spectra, the first considerable Cerealia peak was detected.

\section{LPAZ IV-3300-1300 cal BC (4500-3000 BP)}

The Quercus curve ranged between 20-40\% and increased percentages of Fagus and Carpinus were observed. Poaceae had a value of $20-40 \%$. Cerealia was constantly present, while Pediastrum almost disappeared. The amount and diversity of herbaceous pollen increased substantially.

The vegetation mosaic described above implies that in this region both human activities and climatic changes in the vegetation. We make these assumptions based on the following reasons:

- The analysis of the main components of the tree taxa showed a change in the deciduous trees versus Pinus for Keszthely-Úsztatómajor at $285 \mathrm{~cm}$, while for Fónyed I, this ratio changed at $235 \mathrm{~cm}$. In both cases, the process can probably be attributed to climatic changes.

- Agricultural and settlement land-use may create or increase vegetational mosaics, with development of tracks, fields, and so forth, in which different habitat-preferring flora and fauna elements existed. We expected that the results of the research might provide details about ancient life in the Lake Kis-Balaton region, including information on the natural resources in the area and the relationship of the human population to the physical environment and natural resources through time. However, the paleobotanical analyses indicate that in the study area the proof of human-induced vegetation change was scarce, despite the fact that classical primary pollen (Cerealia) was present.

- No massive signs in vegetational change due to animal husbandry, plant cultivation, or farming were observed. Although a slight change in the ratio of AP and NAP was distinguished during the Copper Age and the appearance of Lengyel culture (4500/4400 cal BC) in the region (Sági 
1996), climatic changes appear to be the driving factor of the vegetation change observed in pollen analysis.

- Signs of forest clearance were not detected during the Neolithic and the Copper Age, but there is a chronological correlation between the increase of Cerealia in the core samples and the known increase in the number of settlements in the region during the Bronze Age.

\section{CONCLUSIONS}

Sedimentary sequences in 2 peat cores from western Hungary were used to reconstruct the environmental history of the region using ${ }^{14} \mathrm{C}$ data, lithography, and pollen analysis. A relatively constant sediment accumulation rate was observed at Keszthely-Úsztatómajor $(23 \mathrm{yr} / \mathrm{cm})$. For Fónyed I, a sharp break was observed in the sedimentation curve around $4800 \mathrm{cal}$ BC (6000 BP). The calculated inverse sedimentation rate was of $33 \mathrm{yr} / \mathrm{cm}$, probably due to flooding followed by a faster sedimentation process, based upon the peak in Pediastrum observed in the pollen diagram.

The pollen profiles indicate the vegetation change on a local landscape scale around Lake KisBalaton from the Early Neolithic to Middle Bronze Age. Woodland appears to have been maintained for most of this time, although there were repeated declines and recoveries of the principal tree taxa. No significant change in the AP and NAP ratio was observed during the Holocene in the region of Lake Kis-Balaton.

Anthropogenic impact was minimal during the studied period, despite the abundant archaeological evidence found in the region. The Copper Age is characterized by sporadic anthropogenic activity. The appearance of higher amounts of cereal pollen at the sites indicated the presence of crop cultivation and we associate this with the development of the Lengyel III culture in the region.

Further changes in the landscape coincided with the appearance of the Baden culture and the period of Early and Middle Bronze Age. However, the role of plant cultivation may have been limited for the ancient inhabitants of the Kis-Balaton region compared to other areas in Hungary due to the limited amount of soil suitable for agriculture and the extensive water table.

\section{REFERENCES}

Berglund GE, Ralska-Jasiewiczowa M. 1986. Pollen analysis and pollen diagrams. In: Berglund BE, editor. Handbook of Holocene Palaeohydrology. Chichester: Wiley. p 455-84.

Birks HJB, Birks HH. 1980. Quaternary paleoecology. In: Kaland PE, Moe D, editors. Quarternary Paleoecology. Baltimore: University Park Press. p 156-76.

Bradley RS. 1985. Quaternary paleoclimatology: methods of paleoclimatic reconstruction. In: Briggs DE, Crowther PR, editors. Quarternary Paleoclimatology. London: Chapman and Hall. 472 p.

Erdtman G. 1943. An introduction to pollen analysis. In: Waltham Verdoorn F, editor. An Introduction to Pollen Analysis. 4th edition. Waltham, Massachusetts: Chronica Botanica Company USA. 139 p.

Faegri K, Iverseon J, Krzywinski K, editors. 1989. Textbook of Pollen Analysis. 4th edition. New York: John Wiley \& Sons. 328 p.

Hertelendi E, Csongor É, Záborsky L, Molnár J, Gál J, Györffi M, Nagy S. 1989. A counter system for highprecision ${ }^{14} \mathrm{C}$ dating. Radiocarbon 31(3):399-406.
Költő L, Vándor L. 1996. Évezredek üzenete a láp világából. A Somogy Megyei Múzeumok Igazgatósága és Zala Megyei Múzeumok Igazgatósága Kaposvár-Zalaegerszeg. (Message of the past from the world of the mire. Archaeological investigations of the Kis-Balaton area.) 165 p. In Hungarian.

Maher L. 1972. Nomograms for computing 0.95 confidence limits of pollen data. Review Palaeobotany and Palynology 13:85-93.

Medzihradszky Zs. 2001a. The Holocene sequence of the pollen record from Keszthely-Úsztatómajor, Hungary. Annales Historico-Naturales Musei Nationalis Hungarici 93:5-12.

Medzihradszky Zs. 2001b. The reconstruction of the vegetation in the Kis-Balaton area during Lengyel period. Preliminary report. In: Regenye J, editor. Sites and Stones: Lengyel Culture in Western Hungary and Beyond. Veszprém: Directorate of the Veszprém County Museums. p 143-8.

Moore PD, Webb JA, Collinson ME. 1991. Pollen analysis. In: Turner HJ, editor. Pollen Analysis. Oxford: 
Blackwell. p 130-96.

Pilcher JR. 1993. Radiocarbon dating and the palynologist: a realistic approach to precision and accuracy. In: Chambers FM, editor. Climate Change and Human Impact on the Landscape. London: Chapman and Hall. p 23-32.

Reille M. 1992. Pollen et spores d'Europe et d'Afrique du Nord. Laboratoire de Botanique Historique et Palynologie. URA CNRS, Marseille. $520 \mathrm{p}$.

Reille M. 1995. Pollen et spores d'Europe et d'Afrique du Nord. Laboratoire de Botanique Historique et
Palynologie. URA CNRS, Marseille. 327 p.

Sági K. 1966. Magyarország régészeti topográfiája I. Veszprém megye. A keszthelyi és tapolcai járás. (Archäologische Topographie Ungarns. Kreise von Keszthely und Tapolca im Komitat Veszprém.) Budapest: Akadémiai Kiadó. 266 p. In Hungarian.

Stockmarr J. 1971. Tablets with spores used in absolute pollen analysis. Pollen et Spores 13:615-21.

Stuiver M, Reimer PJ. 1993. Extended ${ }^{14} \mathrm{C}$ database and revised CALIB radiocarbon calibration program. Radiocarbon 35(1):215-30. 